\title{
Lifestyle and wellness - effects on cardiovascular disease risk factors
}

\author{
Witold Pawłowski' ${ }^{1}$, Krzysztof Goniewicz ${ }^{2}$, Mariusz Goniewicz ${ }^{3}$, Dorota Lasota ${ }^{4}$ \\ ${ }^{1}$ Medical University of Warsaw, Department of Disaster Medicine \\ ${ }^{2}$ Polish Air Force Academy, Faculty of National Security and Logistics \\ ${ }^{3}$ Medical University of Lublin, Department of Emergency Medicine \\ ${ }^{4}$ Medical University of Warsaw, Department of Experimental and Clinical Pharmacology
}

Pawłowski W, Goniewicz K, Goniewicz M, Lasota D. Lifestyle and wellness: effects on cardiovascular disease risk factors. Med Og Nauk Zdr. 2018; 24(4): 228-233.

\begin{abstract}
Introduction. Lifestyle is one of the factors influencing people's health and each person should be responsible for own health. Hence, it is necessary to educate people about importance of proper choices of behaviour and life style that have substantial influence on health. Such choices are called 'pro-health' and have a positive impact on health improvement. Healthy attitudes are 'all feelings (emotions), beliefs, opinions, evaluations, views about health as a high value'. The ideal attitude towards health is a strict, consequent attitude characterized by substantial knowledge, awakened feelings and motivations, and particular plans of action, each element being coherent with the others. The shaping and modification of attitudes is based on fixing positive and eliminating negative influences on health. Nowadays, circulatory system illnesses are one of the main risks for health and life of people worldwide. They are the main reason for deaths in the European Union and amount to $40 \%$ of all deaths. In Poland, the death rate due to this type of illness is one of the highest in Europe. The study presents the risk for the factors for cardiovascular disease and characterizes their influence on lifestyle and wellness. Conclusions. In order to reduce and limit the incidence rate of circulatory system diseases it is necessary to promote knowledge about the essence of these illnesses and about the benefits resulting from a healthy style of life. Promoting healthy life attitudes eliminates such risk factors as smoking, alcohol drinking, improper nutrition habits, and lack of physical activity.
\end{abstract}

\section{Key words}

disease factors, wellness, lifestyle, health behaviours, cardiovascular diseases

\section{INTRODUCTION}

A lifestyle is one of the factors influencing people's health, and each person should be responsible for own health. Hence, it is necessary to educate people about importance of proper choices of behaviour and life style that substantially influence health. Such choices are called 'pro-health' and have positive impact on health improvement. Healthy attitudes are 'all feelings (emotions), beliefs, opinions, evaluations, and views about health as a high value' [1]. The ideal attitude towards health is a strict, consequent attitude characterized by substantial knowledge, awakened feelings and motivations, and particular plans of action, with every element being coherent with another. The shaping and modification of attitudes is based on fixing positive and eliminating negative influences on health. Health-related activities include: action fostering health-positive and pro-health, e.g. proper physical activity, proper nutrition and stress handling. Activities detrimental to health, i.e. negative and anti-health, include smoking, alcohol abuse and improper nutrition. Pro-health activities are one's pursuits towards the highest health level and anti-disease and complications activities. Anti-health behaviours are the opposite to the above [2].

Lifestyle is a wide term - it includes people's behaviour, such as physical activity, nutrition programme, addictions, ways of treatment and taking medicines. Lifestyle is the most influential factor on health. It determines the health

Adress for corespondence: Witold Pawłowski, Medical University of Warsaw, Department of Disaster Medicine

E-mail: witold.pawlowskl@dr.com

Received: 28 July 2018; accepted: 8 September 2018 condition of individuals and whole populations $[3,4]$. According to the WHO:

... lifestyle is based on mutual relations between life conditions and individual behavior patterns determined by social and cultural factors and individual person's traits. The scope of behavior patterns for A particular individual can be limited to or extended by environmental factors and individual independence. The way in which an individual may contribute to forming behavior patterns - both beneficial and harmful for health.* If one's health condition should be improved, activities must be focused on individual and environmental factors which shape the lifestyle [5].

Every person learns and models own lifestyle every day. Lifestyle and healthy behaviour are related with each other and have mutual influence. The most important are attitudes formed in the very first years of life that can change the person and develop during the socialization process through family standards, social groups and media information. Thus, 'improper behavior shaped during childhood and youth are hard to be changed when being an adult' [6].

Risk factors of circulatory system diseases. According to epidemiologic studies started in the 1940s by such researches as Keys, Dewber, Kannel and Stamler, attention should be paid to factors having influence on circulatory system diseases. The studies showed that people suffering from circulatory system diseases show at least one of many factors that, intrinsically or in combination with others, increases the risk of disease. Until now, about 250 factors of circulatory system diseases factors have been recognized $[7,8]$. The 
most essential issue having influence for health condition is the number of disease factors linked to an individual person. Thus, it is important that every person is aware of the detrimental effects of his/her unhealthy activities, and that knowledge about ways of its prevention, modification and elimination is essential.

In the1980s, it was considered that mostly men suffer from circulatory system diseases and women were naturally protected by hormonal management, especially in the premenopause period. Apart from women suffering from diabetes, smoking a large number of cigarettes a day, and those whose hormonal function of the ovaries ended prematurely, hormonal disorders of women, especially estrogens, have influence on the lipids level growth. The higher the level of low density lipoproteins (LDL) increases, the lower the value of high density lipoproteins (HDL), and the higher the thrombi processes resulting from fibrinogen level growth $[2,9,10]$.

At present, the incidence rate of men and women are considered to be comparable. This results from similar, negative health-related behaviour in both groups - alcohol abuse, smoking and stress $[11,12]$. Along with age, the incidence of circulatory system diseases increases, and the risk is higher in the case of men over 55 years of age and women over the age of 65 . The risk of circulatory system diseases is 2-4 times higher in the case of men over 65 years of age than in case women of similar age. In the case of people suffering from diabetes, cardiovascular diseases develop in both genders at a similar age [13].

Hyperlipidaemia is considered to have a strong influence on the development of circulatory system diseases. Hyperlipidaemia is an increased concentration of fat bodies in blood and include: total cholesterol (TC) and its HDL fractions ('good' cholesterol), LDL ('bad' cholesterol) and triglycerides (TG). Cholesterol and triglycerides are present in the blood in combination with proteins as lipoproteins. LDL cholesterol concentration is responsible for the development of sclerosis; with low LDL concentrations, healthy vascular endothelium and proper arterial pressure, the sclerosis process develops very slowly, or does not develop at all. Exceeding these values is related with higher risk of sclerosis and cardiovascular diseases. The values for diabetics are more rigorous, due to the fact that diabetes itself is a risk factor for cardiovascular diseases $[14,15]$.

Diet also has substantial influence on the presence of cholesterol in the blood. Improper diet, an abundance of food containing large amounts of cholesterol and animal fats, increases LDL concentration. Apart from limiting the consumption of animal fats, the efficient treatment of lipid disorders also includes changing the lifestyle, extending physical activity and body mass reduction. Regular testing of cholesterol level is essential 163].

Many epidemiologic studies show that obesity is related with a higher risk of development of circulatory system diseases, diabetes, hypercholesterolaemia, and causes or intensifies systemic disorders. Obesity is a result of fatty tissues homeostasis disorders, excessive storage of energetic materials in an organism due to lifestyle change, low physical activity and improper nutrition habits. There are many causes of obesity, and it can also be a symptom of various diseases, e.g. diabetes, hypothyroidism, adrenal glands hyperfunction, hormonal disorders, functional disorders of liver, pancreas, alimentary tract, and alienations (including emotional disorders) $[10,11,17]$.
Two types of obesity can be determined: abdominal obesity (androidal), apple type and gluteorum obesity (gynecoid), pear type. Androidal obesity is characteristic mostly for males and consists in fat tissues accumulating in the abdomenal and epigastrium zones. The silhouette of such a person is quite characteristic, while the upper and lower limbs are slim, the trunk is barrel-shaped (large, prominent abdomen). Sometimes, fat tissues lay in the form of large folds; waist-hip ratio is disordered, and people suffering from this type of obesity have a larger amount of released fatty acids. Increased release of these acids increases the production of triglycerides in the liver, and disrupts the proper secretion and functioning of insulin, which leads to a higher concentration of lipids and glycaemia. This type of obesity often causes cardiovascular complications, which means that obese 'apples' are more likely to suffer from circulatory system diseases. Gynecoid obesity is characterized by fat accumulation in the lower parts of body, from buttocks to legs, and is common mostly in women. Most often, it causes thigh varices, osteoarticular system degenerations and metabolic changes which result in higher lipid concentration in the blood (triglycerides), glucose tolerance impairments and insulin resistance $[18,19,20]$.

In order to determine an obesity type, waist-hip ratio is used. This is the quotient of waist circumference and hip circumference (at trochanters level), measured in centimeters. The limits of this ratio are: 0.8 for women and 1.0 for men. Higher WHR value indicates androidal obesity and lower gynecoid obesity $[21,22,23,24]$.

In diagnosing overweight and obesity, the Quetelet index, also called the Body Mass Index (BMI) is used. BMI = weight $[\mathrm{kg}] /$ height $\left[\mathrm{m}^{2}\right]$. Body mass reduction by $10 \%$ decreases the death rate which, according to epidemiologic studies, is the less frequent in the group of people having BMI at 20-25 level, and the majority of deaths occur in the group having BMI over 30. In order to obtain a proper weight, not only proper diet is necessary, but also changing the sedentary lifestyle [10, 11, 20, 23, 24].

Diabetes. Diabetes is a chronic metabolic disease, caused by lack or improper function of insulin. Due to the large number of people suffering from diabetes, it is regarded as one of the most dangerous civilization-related diseases. According to the WHO, prognoses, about 380 million people will suffer from diabetes in 2025. At present, in Poland about 2-2.5 mil people suffers from diabetes, and according to the International Diabetes Federation estimations, diabetes incidence in Poland will be increased by $11-14 \%$ by 2025 . The most common type of diabetes is type 2 , which constitutes disorders in insulin functioning and secretion. Type 1 diabetes, also called insulo-dependent, is caused by the lack of insulin resulting from pancreas tissues impairments. People suffering from type 1 diabetes account for $85 \%$ of all diabetics. Type 2 diabetes is most common in older people, with a similar frequency in men and women, obese people and persons with other metabolism disorders. The very few symptoms of type 2 diabetes development results in a too late diagnosis and less treatment possibilities. People over the age of 60 suffering from the type 2 diabetes more often suffer from cardiovascular diseases (retinopathy, strokes, heart failures, heart ischemia). In this group, heart ischemia is the main cause of death and accounts for $2 / 3$ of all deaths. According to the United Kingdom Prospective Diabetes Study, the predicted longevity of diabetics is shorter by at least 
5-10 years. The reasons for the higher death rate may include disorders impairing heart competence and blood supplies to the heart, and higher coagulation propensity $[2,16]$.

Patients over 60 years of age suffering from circulatory diseases, e.g. hart ischemia, diabetes is an unfavourable prognosis factor. Such people have higher values of diastolic pressure, total cholesterol, symptoms of peripheral vessels diseases, or intensified symptoms of angina pectoris. The main risk factor of diabetes is hyperglycaemia, causing development of cardiovascular system diseases. The higher risk results from the concentration of glycated haemoglobin (HbAlc) over $6.5 \%$, i.e. the upper limit of reference values. United Kingdom Prospective Diabetes Study researchers have shown that coronary disease risk is $11 \%$ higher at $\mathrm{HbAlc}$ value growth by $1 \%$. Other risk factors related with HbAlc are: arterial hypertension, dyslipidaemias and viscera obesity $[2,16]$.

Diabetes is a crucial and independent risk factor of circulatory system diseases. It considerably decreases longevity and impairs the quality of life. It is one of the main reasons for leg amputations, renal failures, and a substantial cause of loss of vision. Early diagnosis and the earliest possible treatment with the usage of modern medicines and change in lifestyle may prevent a patient from serious complications, or even death. In order to increase the safety of diabetics also suffering from circulatory diseases, it is important to strictly control the glucose level and concentration of glycated haemoglobin $[16,17]$.

Arterial hypertension. Arterial hypertension is a common, easy detectable and initially asymptomatic disease consisting in maintained increased values of arterial hypertension, leading to serious organic complications. According to the $\mathrm{WHO}$, it is assumed that the upper limit of systolic blood pressure should be $140 \mathrm{mmHg}$ and $90 \mathrm{mmHg}$ for diastolic blood pressure. When the arterial blood pressure value is higher than the proper ones for several measurements, hypertension is diagnosed [11]. The heart of a person with hypertension encounters higher resistance in blood vessels and needs to work more to keep the blood flowing. An inceased work load on the heart results in an added thickness of its walls and larger left ventricle. There is a gradual development of megalocardia and lower efficiency of cardiac muscle.

Arterial hypertension hastens the formation of sclerosis changes in vessels, resulting in a smaller amount of blood flowing to the heart and decreased heart blood flow. Advanced sclerosis in coronary vessels leads to the narrowing or even closing their diameter, which is the reason for necrosis of a particular area of cardiac muscle - a coronary attack.

In the course of time, blood hypertension causes changes in blood vessels. Arteries become thicker, stiffer, and their diameter is gradually narrowed. The force of blood flow causes mechanical impairment of endothelium and damage to the surface of the thin layer padding the interior of blood vessels. Endothelium impairments leads to increased permeability for substances circulating in the blood and their penetration into the vessel wall, causing structure changes.

The most serious complication resulting from blood hypertension is cerebral function disorder, called a stroke. Decreasing diastolic blood pressure by $2 \mathrm{mmHg}$ may lead to decrease of heart failure risk by $4 \%$, at $5-6 \mathrm{mmHg}$ - to $9 \%$ [8]. Implementation of proper non-pharmacologic and pharmacologic treatment is related with a $30 \%$ lower death risk $[8,11]$.
Improper nutrition. Food is the source of nutritious elements and proper nutrition is one of the most important factors having influence on health. Deficiency of nutritious elements or their excess may directly or indirectly have negative influence on health. Consumption of an excessive amount of food, improper proportions of nutritious elements, insufficient amount of constituents regulating proper organism functioning, i.e. microelements and vitamins, are the causes of serious health problems. Due to improper nutrition habits, the number of people suffering from overweight and obesity is constantly growing, and they also suffer from civilization-related diseases, such as: sclerosis, arterial hypertension, diabetes, tumours, and diseases of the digestive system. Clinical symptoms of circulatory system diseases are present mostly after the $50^{\text {th }}$ year of life in persons consuming large amounts of animal fats and cholesterol rich products, and small amount of fruit and vegetables. The risk of circulatory system diseases results from the unfavourable influence of saturated fatty acids on cholesterol concentration in blood serum and the blood coagulation process due to the low content of antioxidant vitamins $[3,5,11]$. Several studies show that circulatory system diseases are the more common causes of deaths and disabilities in Poland.

Smoking. Smoking is one of the most life and health threatening factors. Every year, about 4 million smokers die due to smoking-related diseases. In Poland, about 10 million people regularly smoke 15-20 cigarettes a day, most of whom are males. In Poland, about 70 thousand people a year die due to smoking-related diseases. The $\mathrm{WHO}$ estimates that almost $50 \%$ of deaths of males aged 35-69 (premature deaths) are the result of smoking. Apart from an increased cholesterol level and hypertension, smoking is one of the main risk factors of circular system diseases.

Inhaling air with cigarette fumes is detrimental to health. The chemical composition of cigarette fumes includes 4,000 substances in the form of tiny molecules and gases, many of which are detrimental: nicotine, carbon oxide, nitrogen oxides, hydrogen cyanide, ammonia, propenal and heavy metals. Nicotine, the basic tobacco constituent, increases the production of adrenaline and noradrenaline, which have an influence on the circulatory system, accelerate the work of the heart, and increases blood flow. Increased blood pressure has a burdening effect on blood vessels. Nicotine has also very harmful influence on the digestive tract, decreases appetite, and disorders the digestion and absorption of food, especially vitamins. It significantly decreases the immunity of the organism. About $10-15 \%$ of red blood cells are deprived of oxygen because of the delivery of carbon oxide. The propensity of thrombocytes to conglomeratie and form thrombi is increased. Carbon oxide impairs blood vessels endothelium, resulting in its higher cholesterol permeability $[11,13]$. The amount of harm caused by smoking depends mainly on the age of the smoker, individual traits of an organism, and the number and quality of cigarettes.

Smoking during pregnancy is very dangerous for the proper development of the foetus, and may result in: miscarriage, development defects, premature delivery, improper position of the foetus, and premature placenta separation [2, 15].

People who smoke not only harm their own health, but also the health those within their environment (passive smokers). In Poland, about 2,000 people die due to passive smoking every year. Nonsmoking waiters and bartenders who work 
in smoky places, suffer from lung cancer twice more often than ones who work in healthy surroundings. Apart from the above- mentioned diseases, passive smoking may lead to allergies and chronic infections of the respiratory tract. It also has a detrimental influence on foetus development and may lead to complications similar to those caused by active smoking. Passive smoking has a significantly bad influence on the circulatory system of children. An infant in whose presence adults smoke cigarettes is burden with a higher risk of Sudden Infant Death Syndrome, asthma, lung and ear infections, and many other diseases [2, 11, 15]. Secondary effects of the influence of nicotine and high risk of smoking-related diseases should make smokers consider quitting smoking, which is expensive and detrimental to health.

Alcohol. According to the WHO, the harmful effects of alcohol drinking are similar to those of smoking. Excessive alcohol consumption is a problem related mostly with Western culture. In Europe, the percentage of the population abusing alcohol is the highest in the world, and has the highest consumption of alcohol per one citizen. It is the cause of $7.4 \%$ of all diseases and premature deaths in the EU, and contributes to large number of road accidents, social problems like violence, hooliganism, criminal acts, family problems, social exclusion and decrease in work efficiency. In Poland, alcohol abuse is a common phenomena and is a serious social and health problem. Both men and women are burdened with this problem and is common mostly among people with a low level of education. The current alcohol consumption in Poland is about 7-8 liters of $100 \%$ alcohol per single citizen $[4,5,6]$. Alcohol causes irreversible changes in the human organism, including the psyche. Alcohol destroys neurons in the cerebral cortex, impairment of blood vessels and digestive tract tissues (stomach, pancreas). Organs at risk of being destroyed by alcohol are the liver and brain. Alcohol abuse causes changes in hormones, skin and tumours. It also has a negative effect on the respiratory tract, immune system and circulatory system. Alcohol has a cardiodepressive effect which results in alcohol cardiomyopathy with circulatory failure, and causes heart rhythm disorders; the latter most often include atrial fibrillation, extra ventricular and supraventricula contractions, and atrioventicular tachycardias. Alcohol is a pathogenic factor of arterial hypertension resulting in hypokalaemia and hypomagnaesemia. It also has a detrimental influence on immune mechanisms. People regularly consuming alcohol very often suffer from various infections, ranging from the common cold to chronic bacterial diseases. Alcohol abuse also has a significant influence on descendants: the children of alcoholics are often sickly and the pace of their psychophysical development is slower than in case of their peers from non-pathologic families. It can also cause physical and psychical addiction and lead to emotional disorders. Very often, alcohol is a cause of road accidents, family quarrels, suicides and murders. People under the influence of alcohol very often cannot control their reflexes as alcohol decreases the ability to think rationally and make proper decisions $[2,11,13]$.

Type A behaviour. Type A people are ambitious who aggressively strive for a professional career. They need selfrealization, striving to be group leaders with uncontested decisions. They have strong will of dominating and achieving successes - both personal and professional. The behavior of type A persons is characterized by a high pace of acting, speaking, movement and lively facial expressions, they have no time to rest and relax. Some studies show that this personality type is related with the risk of cardiovascular diseases. People in this group very often suffer from heart failure, cardiac deaths, heart ischemia and hypertension [14].

Physical activity. Civilization transformations, industrial development, motorization, all these phenomena have resulted in people beginning to value comfort and lack of physical activity. More and more people spend too much time in a sedentary position - at work, in a car or bus, and also during resting. Remaining in sedentary position for many hours a day results in people not having to use their own muscles. A sedentary lifestyle may cause the development of coronary disease, heart failures, obesity, diabetes, haemorrhoids, hypertension and spine or joints illnesses. Lack of physical activity is also related with depression, alcohol abuse and smoking. A passive lifestyle and lack of physical activity influences other risk factors that intensify the chances of circulatory system diseases $[7,18]$. Physical activity is one of the basic needs of a human being at every stage of life, and a properly selected form of physical activity results in a decrease in body mass, improvement in heart dynamics, helps to decrease LDL cholesterol concentration, increases HDL cholesterol concentration and decreases arterial blood pressure. Changing a passive lifestyle into an active one prevents the formation of thrombi in blood vessels, improves well-being, reduces stress, helps in sleeping disorders, and reduces blood coagulability. A proper amount of activity is the duty of every person taking care of own health $[2,7,18]$.

Stress. Stress is an inseparable element of everyoness life, regardless of age and social status. The main sources of stress include relations with other people, conflicts, violence, aggression, rivalry, illnesses, etc. Hans Selye, the author of the stress theory, considered that 'stress, being an external tension factor, makes realization of social needs, tasks, roles for which a person strives, difficult or impossible and causes reduction of self-esteem', and according to Selye, stress is a factor stimulating people's activity. The problem is related with the intensity and frequency of stressors [19]. Stress is a type of external pressure that causes a feeling of internal tension. A person is nervous before solving a difficult problem. One cannot avoid stress, it is present every day in our lives. It is the reaction of an organism to requirements. There is also constructive stress, a positive form, which drives people's actions, stimulates thinking and activity. Generally, negative stress is more common in every day life. So-called destructive stress leads to various illnesses and worsening of the functioning of the organism. Surprising situations, sudden experiences and problems result in serious changes in the organism. During such situations, adrenaline (called the 'stress hormone') is released and It increases arterial blood pressure. A common form of stress manifestation is heart ache. Stress may also result in other psychosomatic symptoms, e.g. heart failure in the course of heart ischemia, sudden increase in arterial blood pressure and heart rhythm disorders (tachycardia, bradycardia) $[9,21]$. 


\section{CONCLUSIONS}

Nowadays, circulatory system illnesses are one of the main risks for health and life worldwide. They are the main reason for deaths in the European Union and amount to $40 \%$ of all deaths (about 2 million a year). In Poland, the death rate due to this type of illnesses is one of the highest in Europe. Circulatory system illnesses are also one of the main causes of chronic diseases that require long and expensive treatment. They have a negative influence on the labour market and are much related with social conditions. Very often, they limit the ability of normal everyday functioning. In order to reduce and limit the incidence rate of circulatory system diseases, it is necessary to promote knowledge about the essence of these illnesses and about the benefits resulting from a healthy style of life. Promoting healthy life attitudes eliminates risk factors such as smoking, alcohol abuse, improper nutrition habits and lack of physical activity. These factors can be reduced through preventive treatment. Due to regular exercising, one can increase the level of HDL cholesterol by almost $7 \%$ in one week. In one year after quitting smoking, the risk of a heart attack is reduced two-fold more than in active smokers. The results of preventive activities can be seen within a short period of time. It is therefore worth to implement such activities as soon as possible in order to live a healthy life.

\section{REFERENCES}

1.Ślusarska, B., \& Nowicki, G. Zachowania zdrowotne w profilaktyce chorób układu krążenia wśród osób pracujących. Problemy Higieny i Epidemiologii, 2010, 91.1.

2. Bułhak-Jachymczyk, B., et. all. Normy żywienia człowieka: podstawy prewencji otyłości i chorób niezakaźnych. Wydawnictwo Lekarskie PZWL 2016.

3. Deeluga, A., et al. The significance of health in the hierarchy of personal values among nurses. Medical Studies/Studia Medyczne, 2018, 34.1: 64-69.

4. Myers, Samuel S., et al. Increasing CO 2 threatens human nutrition. Nature, 2014, 510.7503: 139.

5. Jopkiewicz, A., \& Suliga, E. Biomedyczne podstawy rozwoju i wychowania. Instytut Technologii Eksploatacji-Państwowy Instytut Badawczy.2011.

6. Parizakova, J. Nutrition, physical activity, and health in early life. CRC Press, 2016.
7. Polak, M., et. all. Ocena ryzyka sercowo-naczyniowego przy pomocy funkcji SCORE w odniesieniu do ryzyka określonego na podstawie umieralności z powodu chorób układu krążenia w Polsce. Zdrowie Publiczne i Zarządzanie, 2016, 2015.Numer 4: 328-336.

8. Schaufeli, W. A critical review of the Job Demands-Resources Model: Implications for improving work and health. In: Bridging occupational, organizational and public health. Springer, Dordrecht, 2014. p. 43-68.

9. Szadkowska, I., et. all. Zmienność zachowań zdrowotnych pacjentów z pierwszym zawałem serca leczonych metodą pierwotnej angioplastyki wieńcowej-obserwacja roczna. Hygeia, 2016, 51.1: 77-81.

10.Han, XJ., et al. Clinical application evaluation of Guidelines for Diagnosis and Treatment of Internal Diseases in Traditional Chinese Medicine. Zhongguo Zhong yao za zhi= Zhongguo zhongyao zazhi= China journal of Chinese materia medica, 2017, 42.17: 3233-3237.

11. Ponczek, D., \& Olszowy, I. Styl życia młodzieży i jego wpływ na zdrowie. Problemy higieny i epidemiologii, 2012, 93.2: 260-268.

12. Wloszczak-Szubzda, A., Jarosz, M. J., Goniewicz, M., \& Goniewicz, K. Evaluation of communication and acceptance of the patients by medical personnel. Roczniki Państwowego Zakładu Higieny, 2016, 67.4.

13. Wójtewicz, A. Ciało w kulturze konsumpcji. Efektywność edukacji zdrowotnej na przykładzie sieci szkół promujących zdrowie. Wydawnictwo Naukowe Uniwersytetu Mikołaja Kopernika, 2014.

14. Narkiewicz, K., Opolski, G., Podolec, P., Torbicki, A., \& Zembala, M. Wspólne stanowisko dotyczące rozpoznawania i leczenia zespołu uzależnienia od tytoniu u pacjentów z chorobami układu sercowonaczyniowego. Kardiologia Polska, 2011, 69.1: 96-100

15. Koene, RJ., et al. Shared risk factors in cardiovascular disease and cancer. Circulation, 2016, 133.11: 1104-1114.

16. Leka S. Health impact of psychosocial hazards at work: an overview. 2010.

17. Kowalska, G., Grzyb, B. Stres w życiu człowieka-ujęcie teoretyczne. ROK IX NUMER 4/2015 (29), 2015, 379.

18. Beehr, TA. Psychological stress in the workplace (psychology revivals). Routledge, 2014.

19. Mazur, J. (Ed.). Zdrowie i zachowania zdrowotne młodzieży szkolnej w Polsce: na tle wybranych uwarunkowań socjodemograficznych. Raport z badań HBSC 2014. Instytut Matki i Dziecka, 2015.

20. Ponczek, D., \& Olszowy, I. Styl życia młodzieży i jego wpływ na zdrowie. Problemy higieny i epidemiologii, 2012, 93.2: 260-268.

21. Woynarowska, B., \& Oblacińska, A. Stan zdrowia dzieci i młodzieży w Polsce. Najważniejsze problemy zdrowotne. 2014.

22. Mazur, J., \& Małkowska-Szkutnik, A. Zdrowie i zachowania zdrowotne młodzieży szkolnej na podstawie badań HBSC 2010. Zakład Ochrony i Promocji Zdrowia Dzieci i Młodzieży Instytut Matki i Dziecka, Warszawa, 2011.

23. Brytek-Matera, A. Obraz własnego ciała u otyłych kobiet: przyczyny i stopień niezadowolenia, związek z obniżoną samooceną i strategiami radzenia sobie ze stresem. Psychiatria Polska, 2010, 44.2: 267-275.

24. Sawicka, J. et. all. Wpływ BMI na sposób radzenia sobie z chorobą przez pacjentów kierowanych na zabiegi przezskórnych interwencji wieńcowych. Endokrynologia, Otyłość i Zaburzenia Przemiany Materii, 2010, 6.1: 1-7 


\title{
Styl życia i dobre samopoczucie - wpływ na czynniki ryzyka choroby sercowo-naczyniowej
}

\begin{abstract}
Streszczenie
Styl życia jest jednym z czynników wpływających na zdrowie ludzi. Każdy człowiek powinien być odpowiedzialny za własne zdrowie. Dlatego konieczna jest edukacja mająca na celu wskazanie właściwych wyborów zachowań w zakresie stylu życia, a więc wybór takich, które mają znaczący wpływ na zdrowie. Takie wybory są nazywane prozdrowotnymi i mają pozytywny wpływ na poprawę zdrowia. Zdrowe nastawienie to emocje, przekonania, opinie, oceny, poglądy na temat zdrowia jako wartości. Idealne podejście do zdrowia jest ścisłą, konsekwentną postawą charakteryzującą się wiedzą, uczuciami, motywacjami oraz poszczególnymi planami działań. Kształtowanie i modyfikacja postaw opiera się na ustalaniu pozytywnych i eliminowaniu negatywnych wpływów na nasze zdrowie. Obecnie choroby układu krążenia są jednym z głównych zagrożeń dla zdrowia i życia ludzi na całym świecie. Są one główną przyczyną zgonów w Unii Europejskiej i stanowią 40\% wszystkich zgonów. W Polsce wskaźnik zgonów z powodu tego typu chorób jest jednym z najwyższych w Europie. W pracy przedstawiono ryzyko czynników wpływających na choroby sercowo-naczyniowe oraz scharakteryzowano ich wpływ na styl życia i dobre samopoczucie. W celu ograniczenia częstości występowania chorób układu krążenia konieczne jest promowanie wiedzy o istocie tych chorób oraz o zyskach wynikających ze zdrowego stylu życia. Promowanie zdrowego stylu życia pozwala eliminować czynniki ryzyka, takie jak palenie, picie alkoholu, niewłaściwe nawyki żywieniowe i brak aktywności fizycznej.
\end{abstract}

\section{Słowa kluczowe}

zdrowie, styl życia, czynniki chorobowe, zachowania zdrowotne, choroby układu krążenia 